\title{
Making Sense of Service Recovery in Higher Education Institutions: Exploring the Relationship between Perceived Justice and Recovery Satisfaction
}

\author{
Submitted 29/01/20, 1st revision 12/02/20, 2nd revision 28/02/20, accepted 04/03/20
}

\section{Steven Kayambazinthu Msosa ${ }^{1}$, Nkululeko Fuyane ${ }^{2}$}

\begin{abstract}
:
Purpose: This paper aims to explore the relationship between perceived justice and recovery satisfaction in higher education institutions.

Design/Methodology/Approach: Responses were collected from a purposive sample of 430 full-time students across three public higher education institutions in South Africa using a self-administered questionnaire.

Findings: Based on the data collected, perceived justice viz. interactional and distributive justice is found to have a significant and positive correlation with recovery satisfaction whereas procedural justice has an insignificant and positive correlation with recovery satisfaction.

Practical Implications: The results of this study could prove useful to higher education institutions to ensure that fairness is provided to students during the service recovery process. Furthermore, it offers an opportunity for higher education institutional management to review policies and procedures so that they are responsive to the various needs of students.

Originality/Value: This study makes the first attempt to model perceived justice and recovery satisfaction in the South African higher education sector.
\end{abstract}

Keywords: Recovery satisfaction, perceived justice, distributive justice, interactional justice, procedural justice, higher education institutions.

JEL codes: D63, I23, I24, M31.

Paper type: Research article.

\footnotetext{
${ }^{1}$ Corresponding author, Post-Doctoral Research Fellow, Mangosuthu University of Technology, Department of Marketing, msosa.steven@mut.ac.za

${ }^{2}$ Mangosuthu University of Technology, Department of Marketing, fuyane@mut.ac.za
} 


\section{Introduction}

In sub-Saharan Africa, $6 \%$ of the youth is enrolled at tertiary education institutions compared to $26 \%$, which is the global average. Between 2000 and 2010, there has been a significant increase in enrolment which has doubled from 2.3 million to 5.2 million. This increase is worth celebrating, but the drawback is that the availability of well-trained lecturers, study materials and infrastructure development is lagging and failing to keep pace with the rising student enrolment. Consequently, the quality of education is severely compromised (The Africa-American Institute, 2015). Furthermore, most students have been complaining of bureaucracy which makes it cumbersome for their problems or complaints to be attended to because the processes being used are long and sometimes frustrating. Also, some universities have a problem of poor record-keeping such that students' results cannot be accessed, simply because they cannot be found. As a result, many students are frustrated because they are forced to resit for examination. Students use strikes and protests to convey their grievances to the management of the institutions and in the process, losing valuable time and resources (Bunoti, 2010).

The higher education sector is riddled with many problems that affect the provision of quality service at various higher education institutions. When the service rendered does not meet the expectation of the students, the service is deemed to have failed. Thus, the failure to deliver quality service leads to unfavourable students' reactions such as strikes, protests and boycotts which subsequently delay the completion of the academic calendar (Hlophe, 2016; Dawood and Peters, 2016). In some cases, different initiatives to prevent the occurrence of service failure do not yield the desired results. As such, universities are found in a situation where they must make up for their mistakes.

However, the challenge is that some university employees are clueless. They do not have the knowledge, expertise and skills to address service failure incidents arising from unmet student expectations. Therefore, service recovery cannot be ad-hoc either and, if universities have a keen interest in addressing service failure incidents, they must put in place strategies, policies and procedures and empower their employees with skills to enable them to implement effective service recovery strategies (Rashid, Ahmad and Othman, 2014). The primary purpose of this study is to examine the relationship between perceived justice and recovery satisfaction in higher education institutions. To achieve this, an analysis of the relationship between perceived justice viz. interactional, distributive and procedural justice and recovery satisfaction will be conducted.

This paper has been organised as follows: Section 2 discusses the relevant literature of this study by highlighting the social exchange and equity theory, perceived justice, and recovery satisfaction. Section 3 presents the methodology that was used, section 4 discusses the analysis and findings of this study. Section 5 provides a discussion of the results by comparing the current findings with previous studies. 
Lastly, section 6 highlights the conclusions and some policy implications that this study may have in the higher education sector.

\section{Literature Review}

\subsection{Social Exchange and Equity Theory}

Service recovery and the concept of justice are based on social exchange and equity theories. The notion of justice or fairness refers to the positive function of the student and institution outcome and a negotiated function of the student and institution inputs. Social exchange and equity theories are important theories that provide the basis for the application of the service recovery process in general and perceived justice in particular. Thus, it is expected that institutional employees must have an understanding of the fundamental principles of the two theories if the service recovery process is to yield the desired result, which is recovery satisfaction (Oliver and Swan, 1989). Yim et al. (2003) aver that effective implementation of service recovery can only be achieved if service providers have an understanding of the psychological process in evaluating service failure and the service recovery effort. In this regard, an understanding of equity and social exchange theories is needed.

Maxham and Netemeyer (2002) have described how human beings behave during service recovery using social exchange and equity theories. Equity theory assumes that an individual will experience inequity when efforts are undertaken to compare the ratios of his input to outcomes with those of other individuals (Prasongsukarn and Patterson, 2012). Thus, during service recovery, students compare their inputs against outputs when measuring the service recovery process. Inputs can be seen as costs associated with service failures such as financial, time, energy and psychic costs, whereas outputs simply means the specific service recovery initiative or effort such as compensation, speed, apology, empowerment, explanation and service policies designed to help in resolving service failure incidents (Hoffman and Kelly, 2000). Social exchange theory is used to explain students' perceptions of justice. It helps in explaining how students evaluate exchanges which include processes used when delivering the service and outcomes of the core service delivered (Smith, Bolton and Wagner, 1999). Three dimensions of justice viz. distributive justice (which deals with outcomes of the core service), procedural justice (which deals with the processes used to deliver the service) and interactional justice (which deals with the interpersonal nature of the interaction during the service recovery process) are very important elements for managing the service recovery process (Prasongsukarn and Patterson, 2012).

\subsection{Perceived Justice}

The concept of justice has been defined by many scholars as perceived compliance with rules that express appropriateness in the context of decisions. Organizational 
justice demonstrates the extent to which an organization or executive management is perceived to act consistently, equitably and truthfully in making decisions (Colquit and Rodell, 2015). Another school of thought suggests that service recovery justice is perceived as the student's evaluation of fairness in which the service failures are handled in a manner that reflects distributive, procedural and interactional justice (Huang et al., 2015). Perceived justice is regarded as a three-dimensional construct that encompasses distributive justice (perceived fairness of remedies or mitigating initiative by the institution), procedural justice (perceived fairness of the service provider's return and exchange policy) and interactional justice (perceived fairness of feedback by the institution to the complaint launched by the student) (De Matos, Viera and Veiga, 2012).

\subsubsection{Distributive Justice}

Distributive justice is based on equity theory because it is premised on the understanding of how students respond to outcome distribution. Students seek to maximize gains and minimize losses in the distribution of outcomes (Martinez-Tur, et al., 2006). Thus, distributive justice is regarded as what the student receives as an outcome of the service recovery process. For example, a replacement for incorrect marks or an apology for a delayed class (McColl-Kennedy and Sparks, 2003).

Distributive justice depends on student feelings of equity which triggers the need to compare input costs with the received outcomes. Received outcomes may include reimbursements, apologies, discounts and refunds (Ibrahim and Abdallahamed, 2014). The need for error-free service delivery cannot be overemphasized as it is key to ensuring student satisfaction and retention.

Distributive justice or monetary compensation is not adequate to cover for the poor service delivered and, in some cases, it is not just necessary, but it is crucial for service providers to administer the service in a manner that meets student expectations because some students will not value the service providers' recovery efforts. They do not want to give the service provider a chance to correct the mistakes (Xu, Tronvoll and Edvardsson, 2014).

\subsubsection{Procedural Justice}

Procedural justice is deemed as fairness in the process undertaken to achieve an outcome or service recovery from service breakdown. Procedures can only be deemed to be fair if they are accessible, flexible, convenient, timely and provide students with an opportunity to share their ideas on the recovery decision process (Boshoff, 2014). Conversely, it must be noted that procedural justice can be spoilt by rude members of staff, impersonal interaction style of acquiring student information and communicating the outcome (Stone, 2011). A fair procedure should have three components, i.e. the service provider taking responsibility for the service breakdown, complaints being dealt with promptly and, lastly, system flexibility that takes cognizance of individual circumstances and student feedback regarding the ideal or expected outcome (Siagian and Triyowati, 2015). 


\subsubsection{Interactional Justice}

Several scholars have come up with different perspectives regarding the components or elements of interactional justice. Interactional justice demands that the treatment of individuals should be done with politeness, courtesy, respect and empathy after registering their complaint with the organization (Boshoff, 2014). Another school of thought suggests that interactional justice relates to fairness in the manner of interaction between institutional employees and the students (Tsai, Yang and Cheng, 2014). Xiao and Omar (2014) have noted that interactional justice has five components, i.e. explanation, honesty, politeness, effort and empathy. Ho, Tojib and Khajehzadeh (2017) warn that student rationality in the event of service unfairness depends on the actions of members of staff. It is, therefore, essential to managing student impressions by encouraging them to express their opinions promptly when something goes wrong. Training of members of staff should focus on inculcating a culture of responding positively to student queries by showing positive attitudes.

\subsection{Recovery Satisfaction}

The pursuit of impeccable service quality in universities is an ongoing struggle because the expectations and perceptions of students are not static and can change with time and context (Yeo, 2008). Student expectations are critical in determining student satisfaction both prior and after a service failure. Provision of adequate information to students before enrollment is vital in building student expectations of various aspects of university services. The absence of information concerning services offered by higher education institutions might build fuzzy students' expectations of the services available and subsequently affect their satisfaction (Sultan and Wong, 2011). Student satisfaction is the degree to which the value offering of the institution meets or exceeds the expectations of the student, whereas recovery satisfaction refers to the degree to which service recovery initiatives have yielded positive results by way of meeting or exceeding student expectations after encountering a service failure (Walter, Chituru and Chibunna, 2015).

In highly competitive markets of international education, many institutions are offering homogenous services and the only way to create a name or reputable brand is by having students who are satisfied with the service offering. Student satisfaction is based on how the service is delivered by institutional employees such that if students' expectations are met, they will be satisfied and delighted if they are exceeded (Ndanusa, Harada and Abdullateef, 2014). Students who are satisfied with service recovery have their confidence restored in the service provider. In order to sustain satisfaction, the student must perceive fairness in the recovery process. Therefore, frequent evaluation of service quality, training for employees and setting up service delivery or working standards are some of the measures that can be adopted to prevent service failure and achieve recovery satisfaction (Siu, Zhang and Yau, 2013). 


\subsection{Relationship between Perceived Justice and Recovery Satisfaction}

Student satisfaction in the event of service failure is based on several factors such as proper compensation, fair outcome, sincerity, empathy, politeness, timely outcome, fair policies and procedures. Extant research on service recovery in Pakistan higher education institutions has found a significant relationship between distributive justice and recovery satisfaction (Waqas, Ali and Khan, 2014). A study on the effects of justice on service recovery satisfaction on Metro Manila diners found that distributive justice has a stronger correlation with recovery satisfaction compared to other dimensions (Tan, 2014).

Several studies that have been conducted in different sectors have found a significant correlation between interactional justice and recovery satisfaction (Smith and Mpinganjira, 2015). Another study on service recovery and justice dimensions in Istanbul found a significant and stronger relationship between interactional justice and recovery satisfaction (Esen and Sonmezler, 2017). A similar study on perceived justice and recovery satisfaction found that interactional justice affects recovery satisfaction significantly (Jha and Balaji, 2015). Siu, Zhang and Yau (2013) have noted that there is a positive and significant correlation between procedural justice and recovery satisfaction, whereas interactional justice is insignificant. Jung and Seock (2017) conducted a study on service recovery and the findings show a significant relationship between procedural justice and recovery satisfaction more than any of the other dimensions.

\section{Research Methodology}

The research was conducted across three public universities in South Africa. A total of 430 full-time students were used as respondents in this study. A purposive sampling technique was used to select respondents because of the absence of a sampling frame. In addition, the researcher wanted to interact with students who have experienced service failure and have gone through the service recovery process. Purposive or judgmental sampling uses the researcher's discretionary choice of a respondent due to the qualities the respondent possesses (Bernard, 2002; Lewis and Sheppard, 2006).

A quantitative, descriptive and cross-sectional study was adopted. Quantitative research is often associated with descriptive research, and it provides predetermined answers or options to many research participants. The main goal of the quantitative study is to predict relationships and test hypotheses. Furthermore, the results of a quantitative study can be projected onto the population of interest (Hair, Celsi, Ortinau and Bush, 2013). Data analysis was done by means of a SmartPLS3. This study used a confirmatory factor analysis (CFA) to ascertain if the criteria that are acceptable for ascertaining reliability and validity were achieved. Thus, reliability being the magnitude to which variables evaluated by a multiple-item scale, show the real estimates of the variables corresponding to the error (Hulland, 1999; Aibinu and 
Al-Lawati, 2010). Table 1 shows that composite reliability and Cronbach's alpha scores were above 0.7 . This means that reliability scores for all the variables (Distributive justice $=0.918$, Interactional justice $=0.931$, Procedural justice $=0.946$ and Recovery satisfaction $=0.934$ ) were acceptable (Fornell and Larcker, 1981; Henseler, Ringle and Sinkovics, 2009; Bagozzi and Yi, 2012).

Table 1. Construct reliability and validity

\begin{tabular}{|c|c|c|c|c|}
\hline Factors & $\begin{array}{l}\text { Cronbach's } \\
\text { Alpha }\end{array}$ & rho_A & $\begin{array}{l}\text { Composite } \\
\text { Reliability }\end{array}$ & $\begin{array}{l}\text { Average Variance } \\
\text { Extracted (AVE) }\end{array}$ \\
\hline Distributive justice & 0.918 & 0.919 & 0.918 & 0.738 \\
\hline Interactional justice & 0.931 & 0.932 & 0.931 & 0.693 \\
\hline Procedural justice & 0.946 & 0.947 & 0.946 & 0.746 \\
\hline Recovery satisfaction & 0.934 & 0.934 & 0.934 & 0.825 \\
\hline
\end{tabular}

Discriminant validity shows the degree to which a given variable is unique from other variables (Suki, 2011). Thus, the frequently adopted measure of statistics for ascertaining discriminant validity is by comparing the Average Variance Extracted (AVE) (Henseler et al. 2009) with the correlated squared root (Spiegel, 1972):

$$
r=\frac{\sum\left(x_{i}-\bar{x}\right)\left(y_{i}-\bar{y}\right)}{\sqrt{\sum\left(x_{i}-\bar{x}\right)^{2}\left(y_{i}-\bar{y}\right)^{2}}}
$$

Thus, in order to reach the acceptable threshold of discriminant validity, the average variance extracted of a variable ought to have a greater value than the square root of the inter factor correlations (Fornell and Larcker, 1981). The AVE in the current study are highlighted in bold along the diagonal $(\mathrm{DJ}=0.859 ; \mathrm{IJ}=0.832 ; \mathrm{PJ}=0.864$ and $\mathrm{RS}=0.908$ ) as shown in Table 2.

Table 2. Factor AVE and correlation measures (Fornell-Larcker criterion)

\begin{tabular}{lllll}
\hline Factor & DJ & IJ & PJ & RS \\
\hline DJ & 0.859 & & & \\
IJ & 0.767 & 0.832 & & \\
PJ & 0.825 & 0.844 & 0.864 & 0.908 \\
RS & 0.792 & 0.803 & 0.811 & \\
\hline
\end{tabular}

Note: the values in bold along the diagonal are the square root of AVE for each factor. DJ (Distributive justice), IJ (Interactional justice), PJ (Procedural justice), RS (Recovery satisfaction).

\section{Research Results}

In this study, each causal path was determined by analysing the beta $(\beta)$ value (positive or negative) and statistical significance (t-value) to ascertain its corresponding route. Thus, the bootstrapping method in the SmartPLS3 was utilised 
to determine the strength of the relationship. According to Keil et al. (2000), for any causal path to be admissible, the t-value should be more than 2.0 at a significance level of 0.01 . In this regard, the relationship between perceived justice and recovery satisfaction was evaluated, bearing in mind the protocol observed in the preceding statistical explanation. Firstly, as shown in Table 3, this study evaluated the relationship between distributive justice and recovery satisfaction. The findings show a positive and significant correlation $(\beta=0.215$, t-value $=3.336, p=0.001)$. A similar test was done to ascertain the relationship between procedural justice and recovery satisfaction. The finding of this study indicates that there was a positive and insignificant correlation $(\beta=0.041$, $\mathrm{t}$-value $=0.486, \mathrm{p}=0.627)$. As shown in Table 3 , this study further evaluated the relationship between interactional justice and recovery satisfaction. The findings indicate a significant and positive correlation $(\beta=0.219$, $\mathrm{t}$-value $=2.958, \mathrm{p}=0.003)$.

Table 3. Results of the relationship between perceived justice and recovery satisfaction

\begin{tabular}{llllll}
\hline Factors & $\begin{array}{l}\text { Original } \\
\text { Sample }(\mathrm{O})\end{array}$ & $\begin{array}{l}\text { Sample } \\
\text { Mean }(\mathrm{M})\end{array}$ & $\begin{array}{l}\text { Standard } \\
\text { Deviation } \\
(\text { STDEV })\end{array}$ & $\begin{array}{l}\text { T-Statistics } \\
(|\mathrm{O} / \mathrm{STDEV}|)\end{array}$ & P-Values \\
\hline DJ -> RS & 0.215 & 0.217 & 0.064 & 3.336 & 0.001 \\
IJ -> RS & 0.219 & 0.218 & 0.074 & 2.958 & 0.003 \\
PJ -> RS & 0.041 & 0.040 & 0.084 & 0.486 & 0.627 \\
\hline
\end{tabular}

Note: SE (standard error), $n s$ (not significant), $* p<0.05$, $* * p<0.01, * * * p<0.001$ (two-tailed $t$-tests). DJ (Distributive justice), IJ (Interactional justice), PJ (Procedural justice), RS (Recovery satisfaction).

As shown in Table 4, all theorised paths viz. distributive justice -> recovery satisfaction and interactional justice -> recovery satisfaction was significant, whereas procedural justice -> recovery satisfaction was insignificant.

Table 4. Summary of the results of the relationship between perceived justice and recovery satisfaction

\begin{tabular}{lllll}
\hline Factors & $\begin{array}{l}\text { Original Sample } \\
(\mathrm{O})\end{array}$ & $\begin{array}{l}\text { T-Statistics } \\
(\mid \mathrm{O} / \mathrm{STDEV})\end{array}$ & P-Values & Result \\
\hline DJ->RS & 0.215 & 3.336 & $0.001^{* * *}$ & Supported \\
IJ-> RS & 0.219 & 2.958 & $0.003^{* * *}$ & Supported \\
PJ->RS & 0.041 & 0.486 & $0.627^{\mathrm{ns}}$ & Unsupported \\
\hline
\end{tabular}

Note: SE (standard error), $n s$ (not significant), ${ }^{*} p<0.05, * * p<0.01, * * * p<0.001$ (two-tailed t-tests). DJ (Distributive justice), IJ (Interactional justice), PJ (Procedural justice), RS (Recovery satisfaction).

\section{Discussion}

Service recovery in institutions of higher learning was reviewed by exploring the relationship between perceived justice and recovery satisfaction. Firstly, the 
relationship between distributive justice and recovery satisfaction showed a positive and significant relationship. The findings of this study agree with a similar study in South Africa which found a positive and significant relationship between distributive justice and recovery satisfaction (Petzer, De Meyer-Heydenrych and Svensson, 2017). Similarly, Joosten, Josée Bloemer and Hillebrand (2017) found a significant and positive relationship between distributive justice and recovery satisfaction. Furthermore, a study conducted on perceived justice in Indonesia by Ellyawati, Pharmmesta, Purwanto and Herk (2013) found that distributive justice has a significant relationship with service recovery.

In addition to the above, this study evaluated the relationship between procedural justice and recovery satisfaction. The results showed a positive and insignificant relationship. Thus, the findings in this study corroborate the study conducted in Brazil which found a positive and insignificant relationship between procedural justice and recovery satisfaction (Lopes and da Silva, 2015). Similarly, another school of thought avers that the impact of procedural justice is insignificant because institutions do not usually allow students to appreciate the internal processes being used to address complaints and that students can only make inferences into the fairness of procedures by observing the actions of front desk personnel.

However, this does not provide a full account of the internal processes being used (Gelbrich and Roschk, 2011). Conversely, the findings differ from various studies that have found a positive and significant relationship between procedural justice and recovery satisfaction (Smith and Mpinganjira, 2015). Furthermore, Jha and Balaji (2015) have observed that one of the fundamental requirements of the service recovery process is procedural justice such that a low level of procedural justice can awaken negative emotions which may eventually lead to double deviation. Lastly, this study analyzed the relationship between interactional justice and recovery satisfaction. The findings showed a positive and significant relationship. Similarly, a study undertaken by Petzer et al. (2017) found that the relationship between interactional justice and recovery satisfaction was positive and significant.

\section{Conclusions and Policy Implications}

This study examined the relationship between perceived justice and recovery satisfaction in higher education institutions. The findings showed that interactional and distributive justice have a significant and positive correlation with recovery satisfaction. On the other hand, the findings showed that procedural justice has an insignificant and positive correlation with recovery satisfaction. Based on these findings, higher education institutions should endeavor to enhance fairness by reviewing and redesigning their policies and procedures. In this regard, there is a need to conduct a system audit that will help in identifying specific areas that are hindering the smooth running of the institution and interface between departments. For example, higher education institutions can undertake an audit with the view to analyzing the effectiveness of procedures in respect of students' registration, 
accommodation, the library, finance and accounting. There is also a need for HEIs to improve the way they interact with students. Such can be achieved if the institutions show empathy, keen interest and understanding in resolving students' grievances.

However, the challenge is that sometimes a lack of proper interaction between the students and employees of the institutions during service recovery hinders the realization of the satisfactory student experience. Thus, interactive communication is a fundamental aspect of the service recovery process and helps both parties to a transaction to design a seamless way of managing the service recovery process and ultimately achieving recovery satisfaction. Besides, higher education institutions must ensure that the outcome of the service recovery process is fair, acceptable and meets students' expectations if they are to achieve recovery satisfaction.

The current study has contributed to the existing literature on perceived justice and recovery satisfaction in the services sector in general and to higher education by demonstrating that students in higher education institutions value both distributive and interactional justice to achieve recovery satisfaction. This finding is very critical for higher education institutional managers to frequently review and improve how university employees interact with students. Thus, such a review process can help in creating a conducive environment where university employees appreciate the need to provide a fair outcome and treat students with respect, politeness, empathy and courtesy because these aspects are critical to achieving recovery satisfaction. This study has several limitations. Firstly, the study was conducted across three universities in South Africa such that the results cannot be generalized beyond this context but can be helpful to other education institutions with similar management set up. In addition, there is a need to cautiously generalize this study because the sample size used was small. Future research should investigate perceived justice and other variables such as trust in higher education and other sectors.

\section{References:}

Aibinu, A.A., Al-Lawati, A.M. 2010. Using PLS-SEM technique to model construction organizations' willingness to participate in e-bidding. Automation in Construction, 19(6), $714-724$.

Bagozzi, R.P., Yi, Y. 2012. Specification, evaluation and interpretation of structural equation models. Journal of the Academy of Marketing Science, 40(1), 8-34.

Bernard, H.R. 2002. Research Methods in Anthropology: Qualitative and quantitative methods. 3rd edition. California: Altamira Press.

Boshoff, C. 2014. The influence of buffering variables on clients' willingness to engage in retribution behavior after a service failure. South African Journal of Economics and Management, 17(3), 297-309.

Boshoff, C. 2014. Services marketing: A contemporary approach. $2^{\text {nd }}$ ed. Cape Town: Juta.

Bunoti, S. 2010. The quality of higher education in developing countries needs professional support. Available online: http://www.intconfhighered.org/FINAL\%20Sarah\%20Bunoti.pdf. 
Cengiz, E., Er, B., Kurtaran, A. 2007. The effects of failure recovery strategies on customers behaviours via complaints perceptions of justice dimensions in banks. Banks and Bank Systems, 2(3), 173.

Colquitt, J.A., Rodell, J.B. 2015. Measuring justice and fairness. Oxford Handbook of Justice in the Workplace, 187-202.

Dawood, Z., Peters, S.A. 2016. Durban, PMB students, join protests. Available online: http://www.iol.co.za/dailynews/news/durban pmb-students-join protests-2057028.

Del Río-Lanza, A.B., Vázquez-Casielles, R., Díaz-Martín, A.M. 2013. Satisfaction with service recovery: Perceived justice and emotional responses. Journal of Business Research, (62)8, 775-781.

De Matos, C.A., Viera, V.A., Veiga, R.T. 2012. Behavioral responses to service encounter involving failure and recovery: the influence of contextual factors. The Service Industry Journal, 32(14), 2203-2217.

Ellyawati, J., Dharmmesta, B.S., Purwanto, B.M and Herk, H.V. 2013. Perceived justice in service recovery: a study on experimental design on Indonesian customers. International Journal of Business and Management Studies, (2)2, 1-12.

Esen, S.K., Sonmezler, E.A. 2017. Recovering from services failures: The moderating role of emotional attachment. International Journal of Innovative Research and Development, 6(3), 64-77.

Fornell, C., Larcker, D.F. 1981. Evaluating structural equation models with unobservable variables and measurement error. Journal of Marketing Research, 18(1), 39-50.

Gelbrich, K., Roschk, H. 2011. A meta-analysis of organizational complaint handling and customer responses. Journal of Service Research, 14(1), 24-43.

Hair, J.F., Celsi, M.W., Ortinau, D.J., Bush, R.P. 2013. Essentials of marketing research. $3^{\text {rd }}$ ed. New York, NY, McGraw-Hill.

Henseler, J., Ringle, C., Sinkovics, R. 2009. The use of partial least squares path modelling in international marketing. Advances in International Marketing, 8(20), 277-319.

Huang, S.W., Hung, Y.W., Fu, T.W., Hsu, J.S.C., Chiu, C.M. 2015. Understanding the impact of service failure and recovery justice on consumers' satisfaction and repurchase intention. In the Pacific Asia Conference on Information Systems (PACIS), 55.

Hlophe. 2016. DUT, UKZN resume lecturers under heavy police contingent. SABC. Available online: http://www.sabc.co.za/news/a/176a26004e7d07bf9244965e4966ada6/ DUT, UKZN-resume-lectures-under-heavy-police-contingent-2016051.

Ho, T.H., Tojib, D., Khajehzadeh, S. 2017. Speaking up against service unfairness: The role of negative meta-perceptions. Journal of Retailing and Consumer Services, 35, 1219.

Hoffman, K.D., Kelley, S.W. 2000. Perceived justice needs and recovery evaluation: a contingency approach. European Journal of Marketing, 34(3-4), 418-433.

Hulland, J. 1999. Use of partial least squares (PLS) in strategic management research: a review of four recent studies. Strategic Management Journal, 20(2), 195-204.

Ibrahim, M., Abdallahamed, S. 2014. Service recovery and customer satisfaction: A case of Ugandan Telecom. European Journal of Business and Management, 6(4), 197-209.

Jha, S., Balaji, M.S. 2015. Perceived justice and recovery satisfaction: the moderating role of customer-perceived quality. Management and Marketing, 10(2), 132-147.

Joosten, H., Bloemer, J., Hillebrand, B. 2017. Consumer control in service recovery: beyond decisional control. Journal of Service Management, 28(3), 499-519. 
Jung, N.Y., Seock, Y.K. 2017. Effect of service recovery on customers' perceived justice, satisfaction, and word-of-mouth intentions on online shopping websites. Journal of Retailing and Consumer Services, 37, 23-30.

Keil, M., Tan, B.C., Wei, K.K., Saarinen, T., Tuunainen, V., Wassenaar, A. 2000. A cross cultural study on escalation of commitment behavior in software projects. MIS Quarterly, 24(2), 299-325.

Lewis, J., Sheppard, S. 2006. Culture and communication: can landscape visualization improve forest management consultation with indigenous communities? Landscape and Urban Planning, 77(6), 291-313.

Lopes, E.L., da Silva, M.A. 2015. The effect of justice in the history of loyalty: A study in failure recovery in the retail context. Journal of Retailing and Consumer Services, 24, 110-120.

Martinez-Tur, V., Peiró, J.M., Ramos, J., Moliner, C. 2006. Justice perceptions as predictors of customer satisfaction: the impact of distributive, procedural, and interactional justice. Journal of Applied Social Psychology, 36(1), 100-119.

Maxham, J.G., Netemeyer, R.G. 2002. Modelling customer perceptions of complaint handling over time: the effects of perceived justice on satisfaction and intent. Journal of Retailing, 78(4), 239-252.

McColl-Kennedy, J.R., Sparks, B.A. 2003. Application of fairness theory to service failures and service recovery. Journal of Service Research, 5(3), 251-266.

Ndanusa, M.M.N., Harada, Y., Abdullateef, A. 2014. Determining the mediating effects of student attitude and satisfaction on re-enrollment behavior in Malaysia higher education institutions: Nigerian students experience. Journal of Small Business and Entrepreneurship Development, 2(2), 171-188.

Oliver, R.L., Swan, J.E. 1989. Consumer perceptions of interpersonal equity and satisfaction in transactions: a field survey approach. The Journal of Marketing, 53(2), 21-35.

Petzer, D.J., De Meyer-Heydenrych, C.F. and Svensson, G. 2017. Perceived justice, service satisfaction and behavior intentions following service recovery efforts in a South African retail banking context. International Journal of Bank Marketing, 35(2), 241253.

Prasongsukarn, K., Patterson, P.G. 2012. An extended service recovery model: the moderating impact of the temporal sequence of events. Journal of Services Marketing, 26(7), 510-520.

Rashid, M.H.A., Ahmad, F.S., Othman, A.K. 2014. Does service recovery affect customer satisfaction? A study on co-created retail industry. Procedia-Social and Behavioral Sciences, 130, 455-460.

Siagian, Y.M., Triyowati, H. 2015. Service recovery based on perceived justice: A study on locus attribution. International Journal of Business and Management, 10(7), 99.

Siu, N.Y., Zhang, T.J., Yau, C.J. 2013. The role of justice and customer satisfaction in retention: A lesson from service recovery. Journal of Business Ethics, 114(1), 675686.

Smith, A.K., Bolton, R.N., Wagner, J. 1999. A model of customer satisfaction with service encounter involving failure and recovery. Journal of marketing research, 36, 356372.

Smith, A., Mpinganjira, M. 2015. The role of perceived justice in service recovery on banking customers' satisfaction and behavioral intentions. A case of South Africa. Banks and Bank Systems, 10(2), 35-43.

Spiegel, M.R. 1972. Schaum's outline of theory and problems of statistic. New York: McGraw-Hill. 
Suki, N.M. 2011. A structural model of customer satisfaction and trust in vendors involved in mobile commerce. International Journal of Business Science and Applied Management, 6(2), 18-29.

Sultan, P., Wong, H.Y. 2011. Perspectives of service quality in a higher education context: A qualitative research approach. In: Proceedings of the 24th Annual Australian and New Zealand Academy of Management Conference, Rockhampton.

Stone, M. 2011. Literature review on complaints management. Journal of Database Marketing and Customer Strategy Management, 18(2), 108-122.

Tan, T.A.G. 2014. Effects of justice theory on service recovery satisfaction on Metro Manila dine-in experiences. Philippine Management Review, 21, 25-38.

The Africa-American Institute, 2015. State of education in Africa report 2015: report card on the progress, opportunities and challenges confronting the African education sector. Available online: http://www.aaionline.org/wpcontent/uploads/2015/09/AAISOE-report-2015-final.pdf.

Tsai, C., Yang, Y., Cheng, Y. 2014. Does relationship matter? Customer response to service failure. Managing service quality, 24(2), 139-159.

Walter, A.B., Chituru, O.G., Chibunna, I.E. 2015. Perceived justice initiatives and customers post complaint satisfaction in the fast-food industry. Journal of Marketing and Consumer Research, 14(1), 117-125.

Waqas. M., Khan, M.A., Ali, H. 2014. An investigation of the effects of justice recovery dimensions on students' satisfaction with service recovery in higher education environment. Int Rev Public Non-Profit Mark, 11, 263-284.

Xiao, R.W., Omar, R. 2014. Service recovery activities and customer satisfaction: mediating role of justice dimensions: A Case Study of China. Asian Social Science, 10(18), 253.

Xu, Y., Tronvoll, B., Edvardsson, B. 2014. Recovering service failure through integration. The Services Industry Journal, 34(16), 1253-1271.

Yeo, R.K. 2008. Brewing service quality in higher education: characteristics of ingredients that make up the recipe. Quality Assurance in Education, 16(3), 266-286.

Yim, C.K.B., Gu, F.F., Chan, K.W., David, K.T. 2003. Justice-based service recovery expectations: measurement and antecedents. Journal of Consumer Satisfaction, Dissatisfaction and Complaining Behavior, 16, 36. 